\title{
Forgetting the Shore: Effects of Land Reclamations on Memory of Place in Izmir*
}

\author{
Ahenk Yılmaz**
}

\begin{abstract}
This paper aims to unveil the effects of gradual land reclamations in Izmir on the relationship between place and memory of the shoreline in Punta, Değirmendağ and Konak regions and to explore what is erased and reconstructed as the history of coast in this process. The land reclamations have always been effective in the formation of urban spaces in Izmir, especially along the coastline of the city centre, which perpetually reproduced the inner boundaries of the urban growth. The need for new transportation axes of the city in rapid urbanization process has almost always been met with the new grounds gained from the sea. Each reclamation not only shifted the shoreline, but also destructed either the existing places or their contexts along with their everyday life that they accommodated. In order to give insights into what is lost with each gained ground by means of a backwards place reading, this paper aims to analyze the layers of land reclamations along the shoreline of Punta, Değirmendağı, and Konak regions. With a journey to the past racing back what is forgotten more than what is remembered, the study concludes that overlapped land reclamations gradually eroded the memory of the shoreline and turned it into history, along with certain everyday practices that produce the city culture.
\end{abstract}

Keywords: Memory, shoreline, land reclamation, urban space, Izmir

\section{Özet}

\section{Kıyıyı Unutmak: İzmir'de Kıyı Dolgularının Yerin Belleğine Etkileri}

Bu makale, Punta, Değirmendağı ve Konak bölgelerinin kıyı çizgilerinde aşamalı olarak gerçekleştirilmiş olan sahil dolgularının yer ve bellek ilişkisine olan etkilerini ortaya çıkartmayı ve bu süreçte kentin kıyısının tarihinde silinen ve yeniden inşa edilenleri araştırmayı amaçlar. Kıyı dolguları İzmir'de her zaman kentsel mekânların oluşturulmasında, özellikle kentsel büyümenin içsel sınırlarını oluşturan kent merkezinin sahil bandı boyunca etkili olmuştur. Hızlı kentleşme sürecinde artan yeni ulaşım aksı ihtiyaçları neredeyse her zaman denizden kazanılan yeni yerlerle karşılanmıştır. Her kıyı dolgusu, sadece kıyı çizgisini daha ileriye ötelememiş, aynı zamanda ya var olan mekânları ya da onların bağlamını, imkan tanıdıkları gündelik yaşamlar ile birlikte yok etmiştir. Her kazanılan yer ile kaybedilenlerin içyüzünü anlamak için geriye doğru bir yer okuması aracılığıyla, bu makale, Punta, Değirmendağı ve Konak bölgelerinin kıyı dolgularını katman katman kaldırarak analiz etmeyi hedefler. Neyin hatırlandığından çok neyin unutulduğunun izini süren geçmişe bir yolculuk yaparak, üst üste binen sahil dolgularının kademeli olarak kıyının belleğini, kent kültürünü oluşturan günlük yaşam pratikleri ile birlikte erozyona uğratarak tarihe dönüştürdüğü sonuçlarına ulaşır.

Anahtar sözcükler: Bellek, kıyı, kıyı dolguları, kentsel mekân, İzmir

\section{Introduction}

Most of the citizens of Izmir who pass by Gündoğdu Square today rarely know or think that the land that they gather around Cumhuriyet Ağacı Sculpture was actually sea in the very recent past (Fig. 1). They step on this acclaimed ground, to participate in activities varying from dancing to protest demonstrations on this plaza, or sometimes just to stroll along Kordonboyu, the shoreline. In all

* 18 Şubat 2017 tarihinde Akdeniz Kıyısında İzmir Körfezi ve Bellek başlıklı konferansta sunulan bildiri metninden geliştirilmiştir. Bildiri metni için bkz. Ahenk Yılmaz, "Uzaklaşan Kıyının Unutulan Mekanları", Akdeniz'in Kıyısında İzmir Körfezi Konferans Bildirileri içinde, der. Ayşe Filibeli ve Güzel Yücel Gier (İzmir: İzmir Büyükşehir Belediyesi, 2018), 260-287.

** Yaşar Üniversitesi, Mimarlık Bölümü 


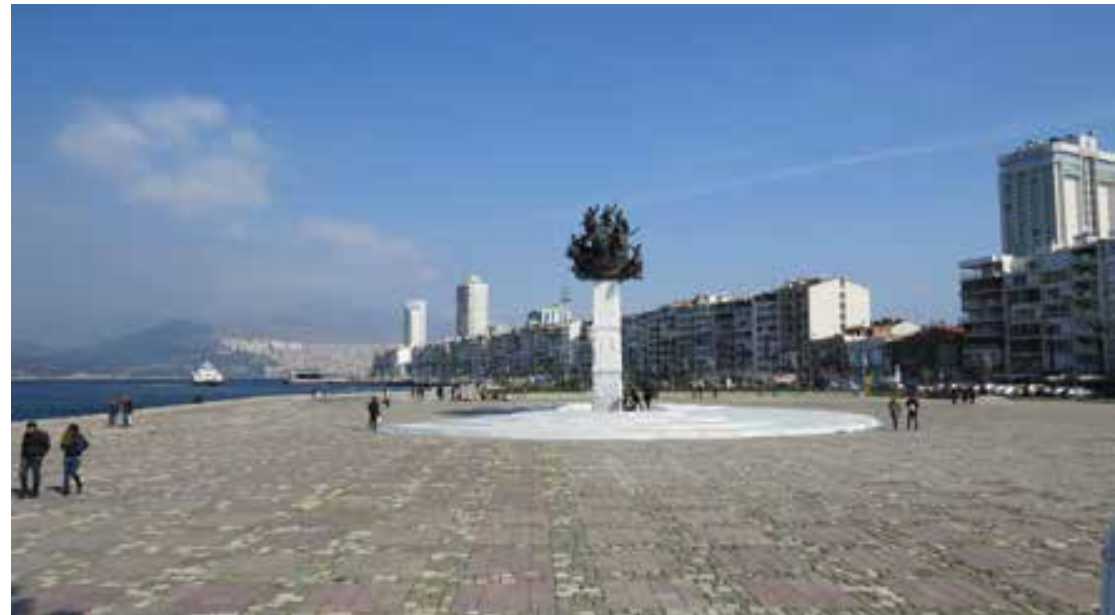

Figure 1. Gündoğdu Square and Cumhuriyet Ağacı Sculpture. Source: Personal Archive.

these activities, they hardly recollect the traces of the forgotten past of this place, because experience is built in place, so is memory, but the power of the present makes this memory not only of a distant past, but also of a place that no longer exists. Today's square does not give any clue about this story of the place and it is not the only case in the city. Izmir's shoreline has been transformed gradually almost for the entire history of the city. Each land reclamation turned the sea into ground, and demolished not only important places of the previous shoreline, but also the collective memory that those places contained.

Land reclamation is defined as "a deliberate enclosure of land or addition of material" to extend the shoreline seawards. ${ }^{1}$ As a deliberate act, it is an urban strategy generally developed to handle urban growth, ${ }^{2}$ and specially to meet industrial and infrastructural needs of growing cities. Due to unexpected growth of rapidly urbanized cities in the course of the 20th century, land reclamations drastically transformed urban topographies of these cities, especially the ones in Far East Asian countries like China, Japan or Singapore. ${ }^{3}$ In spite of this transformation, the impact of reclamations on urban space and its reproduction have rarely been an issue in the current literature. As one of the few scholars, who touch upon this lack, Adam Grydehøj approaches "land reclamation as a political process that entrenches existing power structures while circumventing potentially productive social conflict over the use of urban space." ${ }^{\prime 4}$ Grydehøj describes the effects of reclamation projects on urban space as follows:

1 J. M. Hooke and R. C. Riley, "Historical Changes on the Hampshire Coast, 1870-1965," Proceedings of the Hampshire Field Club and Archaelogical Society, 47 (1991): 217.

2 For example, China's growth model. Mee Kam Ng and Alison Cook, "Reclamation: An Urban Development Strategy Under Fire," Land Use Policy 14 (1997): 8.

3 Yue-man Yeung, "Coastal Mega-cities in Asia: Transformation, Sustainability and Management," Ocean \& Coastal Management 44, no. 5-6 (2001): 323.

4 Adam Grydehøj, "Making Ground, Losing Space: Land Reclamations and Urban Public Space in Island Cities," Urban Island Studies, 1 (2015): 97. 
Land reclamation does not typically seek to "reclaim" lost ground at all but instead to extend solid ground out into new frontiers. Marine spaces often provided the initial rationale for founding human habitations and livelihoods in coastal zones. As a result, terrestrialisation projects - which inevitably alter the nature of adjacent marine spaces, ecosystems, and 'un-reclaimed' shorelines as well as drive subsequent adaptation processes - are far from the straightforward triumphs of material fixity that they first appear or that the 'reclamation' discourse suggests. Flux always begets flux, and the human impetus to construct fixed histories and solid spaces can mask the true consequences of transformative processes. ${ }^{5}$

What these projects conceal, as not only consequences but also motives, constitutes one of the main issues in Grydehøj's research. He claims that the land reclamations in major coastal cities have been popular especially in the course of the 20th century, because there always resides less conflict in reclaiming a new ground for development purposes by local authorities or governments, comparing to the reclamation of existing urban spaces. ${ }^{6}$ In a recent study, Rochana Esti Pramesti argues that "social, economic and environmental functions present in the waterfront are often in competition" because "the need to improve the environment condition or preserve the natural quality does not always go hand in hand with the need to explore waterfront qualities for social and economical gain." ${ }^{\prime 7}$ Land reclamations have always been effective on the formation of the shoreline in Turkey ${ }^{8}$ and more specifically in Izmir, ${ }^{9}$ due to such explorations "for social and economical gain." As a response to the growth of the city and the new needs arising with this growth, local and central authorities of different periods chose to extend the city seawards over centuries. These coastal changes inevitably reproduced not only space but also its collective memory with all its remembered and forgotten aspects. This article attempts to recollect the memory of ever-changing shoreline of the urban center in Izmir through the remembered and forgotten pieces of present urban coastal topography.

\section{History versus Memory: Backwards Reading of Place}

French historian Pierre Nora argues at the beginning of his essay "Between Memory and History" that "we speak so much of memory because there is so little of it left."10 Nora claims that the present-day memory "crystallizes and secretes itself" in the sites of memory [lieux mémoire], "because there are no longer milieux de mémoire, real environments of memory." Sites of memory, according

5 Grydehøj, “Making Ground, Losing Space," 99.

6 Grydehøj, “Making Ground, Losing Space," 107.

7 Rochana Esti Pramesti, "Sustainable Urban Waterfront Redevelopment: Challenge and Key Issues," Media Matrasain 14, no. 2 (2017): 43.

8 Bahar Gedikli, "Kıyıyı Yaşamak, Kıyıı Planlamak," in 7. Kıyı Mühendisliği Sempozyumu Bildiri Kitabı 21-23 Kasım 2011, ed. Prof. Dr. Yalçın Yüksel (Trabzon: TMMOB İnşaat Mühendisleri Odas1, 2011), 23-33.

9 For details about the planning strategies for shorelines in Turkey and recreational land reclamations in Izmir's shoreline see: Pelin Güven, “İzmir Kentinde Rekreasyon Amaçla Yapılan Kıyı Dolgu Alanlarının Peyzaj Planlama Açısından İrdelenmesi: İzmir-İnciraltı Örneği" (Master thesis, Istanbul Technical University, 2000).

10 Pierre Nora, “Between Memory and History: Les Lieux de Mémoire," Representations 26 (1989): 7. 
to him, are the embodiments of memory in certain places such as battlefields, museums, monuments, etc. They are the places "where a sense of historical continuity persists." In fact, for him, "moments of history torn away from the movement of history," and those "moments cannot be lived again." Therefore, they are lieux de mémoire which are "no longer quite life, not yet death." Maurice Halbwachs explores the relationship between memory and history in his last work The Collective Memory. ${ }^{11}$ He claims that as long as the collective memory of a group survives, there is no need to write down the story of the events so there can be no history. ${ }^{12}$ When the time elapses from the event and the collective memory of that event becomes weaker, the event is written down as a record and hence history is created as the reconstruction of the past. Halbwachs ironically defines history as "a crowded graveyard to which new tombstones are continually being added," and poses a question: "How could history ever be a memory, since there is a break in continuity between the society reading this history and the group in the past who acted in or witnessed the event?"13

The shore reclaimed and altered for centuries has turned sea into land, creating new spaces in each move, changing the everyday life by forcing it either to disappear or to linger with different meanings. The storyline of Izmir's shoreline, therefore, consists of a number of breaks initiated mostly by land reclamations. Memory of the shore has been in a state of afflux since the first urbanization acts for Izmir. In fact, memory as "representation of past experiences"14 is not "constant." On the contrary, it is perpetually in a process of reproduction. When recollected individually or collectively, ${ }^{15}$ a new interpretation of the past, along with all the new experiences and traumas of each recalling process, is reconstructed and every time a new memory is produced.${ }^{16}$ Each collective recollection comes along with collective forgetfulness. Just like the two sides of a coin, says Edward Casey, forgetting and remembering complete each other to constitute collective memory. ${ }^{17}$

In his seminal work Remembering: A Phenomenological Study, Casey also concentrates on the role of place in this constant reproduction process. He states that place as a "container of experiences... contributes so powerfully to its intrinsic memorability." Furthermore, "we might even say that memory is naturally place-oriented or at least place-supported."18 Similarly, Dolores Hayden focuses on the importance of place in the preservation of memory asserting that

11 Maurice Halbwachs, The Collective Memory, trans. Francis J. Ditter and Vida Yazdi Ditter (New York: Harper and Row, 1980).

12 Halbwachs, The Collective Memory, 78.

13 Quoted from: Patrick H. Hutton, History as an Art of Memory (Hanover: University Press of New England, 1993), 76.

14 Andreas Huyssen, Twilight Memories: Marking Time in a Culture of Amnesia (London, New York: Routledge, 1994), 3.

15 Richard F. Thompson and Stephen A. Madigan, Memory: The Key to Consciousness (Washington: Joseph Henry Press, 2005), 1.

16 Edward Casey, Remembering: A Phenomenological Study, second edition (Bloomington: Indiana University Press, 2000), xxii.

17 Casey, Remembering, xii.

18 Casey, Remembering, 186-87. 
the historians are just beginning to recognize "the intricate relationship among history, place-specific memory, and the preservation of the urban landscape." For her, the power of place lies beneath the urban landscape to nurture citizens' collective memory.$^{19}$ Hayden concludes that a place-specific memory reading is required for the understanding of the history of cultural landscape. ${ }^{20}$ Based on similar considerations, Walter Benjamin defines urban space as a "battleground for the past," and he argues that understanding cities requires reading them as "topography of collective memory in which buildings are mnemonic symbols which can reveal hidden and forgotten past." ${ }^{21}$ In such reading processes, places, as the geographical subjects of spatial experience become the stages of remembering and forgetting. ${ }^{22}$

Based on this theoretical framework, this article traces back the memory of the shoreline in Izmir through particular mnemonic symbols of the urban landscape. The stories attached to these architectural and urban elements of the shoreline, which whether vanished in the process of land reclamations or survived through adaptations towards their new positions, constitute the focus of this exploration. Starting from the present, this backwards reading focuses on the effects of important land reclamations on the hitherto and/or present shoreline. By means of this reading, the study aims to provide insights into the effects of land reclamation on the memory of place in Izmir. This reading inevitably intertwines with the written history of these places, due to the lack of recorded lived stories especially when the time span increases. Undoubtedly, there are quite a number of places on Izmir's shoreline to carry out this reading. However, this article revolves around three pivotal areas of the shore chosen because of their fundamental role in the development of urban structure of the city: the shorelines of Punta, Değirmendağı, and Konak.

\section{Punta: Where the "Waves Beat the Buildings"}

One of the most important components of urban identity of the city, the shoreline of old Punta region or in other words Kordon ${ }^{23}$ has taken its present view, with its expense green public space used frequently by the citizens, in the process of a new development plan implemented in 1990s. In accordance with the demands of the central government, the General Directorate of Highways decided to connect Mustafa Kemal Coastal Boulevard, which came from the south of the city, to Bornova via a multi-lane highway. ${ }^{24}$ In fact, the nucleus of this de-

19 Dolores Hayden, The Power of Place: Urban Landscapes as Public History (Cambridge, Mass.: MIT Press, 1995), 227.

20 Hayden, The Power of Place, 13.

21 Quoted from: Barbara A. Misztal, Theories of Social Remembering (Berkshire: McGraw-Hill Education, 2003), 16.

22 Abidin Kusno, The Appearances of Memory: Mnemonic Practices of Architecture and Urban Form in Indonesia (Durham, London: Duke University Press, 2010), 11.

23 In a study carried out in 2009 on urban identity, it was asked to Izmir citizens "which word first comes to their minds when its is said Izmir." The first three spelled-out words of the result are; Sea, Kordon, and Clock Tower. See İnci T. Uzun, Didem Akyol Altun and Eylem Bal, “İzmirli’nin İzmir'i: Kentlinin Belleğindeki Mekânsal Temsiller,” Ege Mimarlık 76, no. 1 (2011): 35.

24 Deniz Güner, “From Wreckage to Urban Void: Izmir's Kordonboyu Waterfront Redevelopment," in Architecture in Turkey Around 2000: Issues in Discourse and Practice, ed. Tansel 


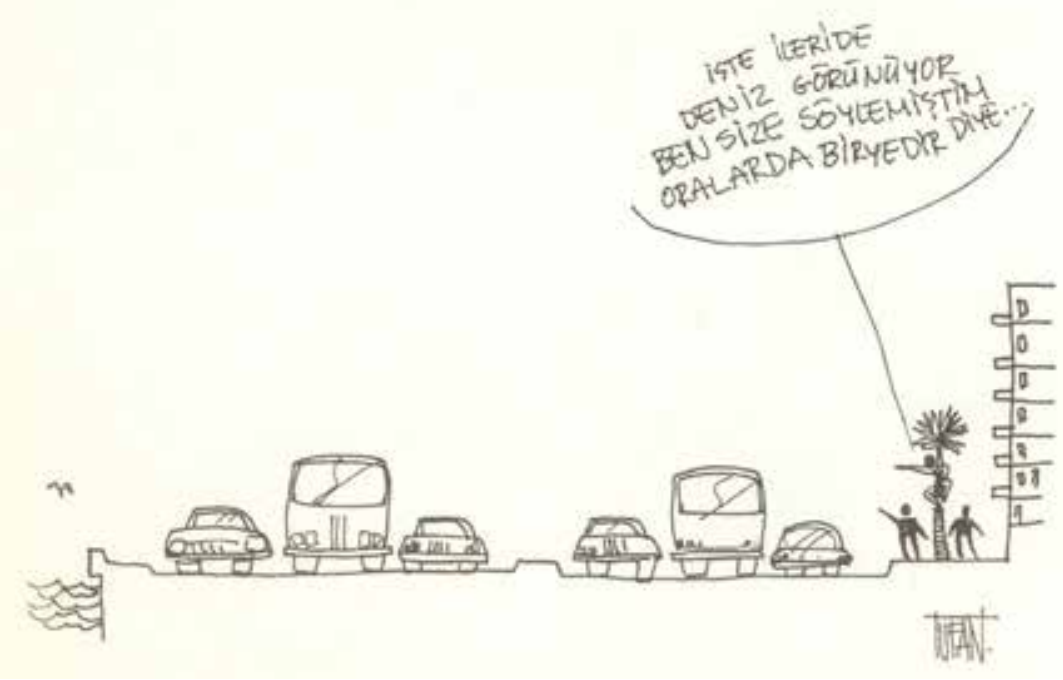

Figure 2. The Caricature by Tufan Arkayın. Source: “Kazıklı Yol... Dolgu Yol... Kordon Yolu... Hizlı Yol, Hiz Yolu," Ege Mimarlık 2 (1992): 32.

cision was visible in the Izmir Master Plan prepared in 1955. The plan projected the transformation of the entire shoreline of the city into a highway from the direction of Çanakkale to Aydin. ${ }^{25}$ In the framework of this decision, the land reclamation work commenced promptly in 1997, and the entire coastal area including the pavement of the two-lane coastal road was covered with soil, rocks and boulders that exceeded even human scale. Not only physical but also visual connection of Kordonboyu with the sea, which inspired many songs and poems for centuries, completely broke off. Despite the decisions of the Conservation Board of Izmir, the local court and Danıştay (Turkish Republic Council of State) to cease the attempt, the construction of the road and the connecting viaducts were completed swiftly before $1998 .{ }^{26}$ As a reaction to this decision, a caricature by Tufan Arkayın, published in the journal of the Izmir Branch of the Chamber of Architects criticizes the land reclamation indicating: "There, the sea appears. I told you that it must be there somewhere"27 (Fig. 2).

With the elections of 1999, the new government abandoned the idea due to the objections raised by the city's leading civil society organizations. ${ }^{28}$ However, at the end of this process, the shoreline had already been extended seawards by meters. The whole process turned the shoreline into "wreckage"29 and left an irreversible imprint on the urban fabric (Fig. 3). In 2000, Izmir Metropolitan

Korkmaz (Ankara: Türkiye Mimarlar Odası, 2005), 75.

25 Güner, "From Wreckage to Urban Void," 74.

26 Hasan Topal, "Kordon Dolgu Alanının Bir Kentsel Mekâna Dönüşümü,” Ege Mimarlık 35, no. 3 (2000): 19.

27 Tufan Arkayın, “Kazıklı Yol... Dolgu Yol... Kordon Yolu... Hızlı Yol, Hız Yolu,” Ege Mimarlık 2 (1992): 32.

28 Güner, "From Wreckage to Urban Void," 75.

29 Güner, "From Wreckage to Urban Void," 75. 


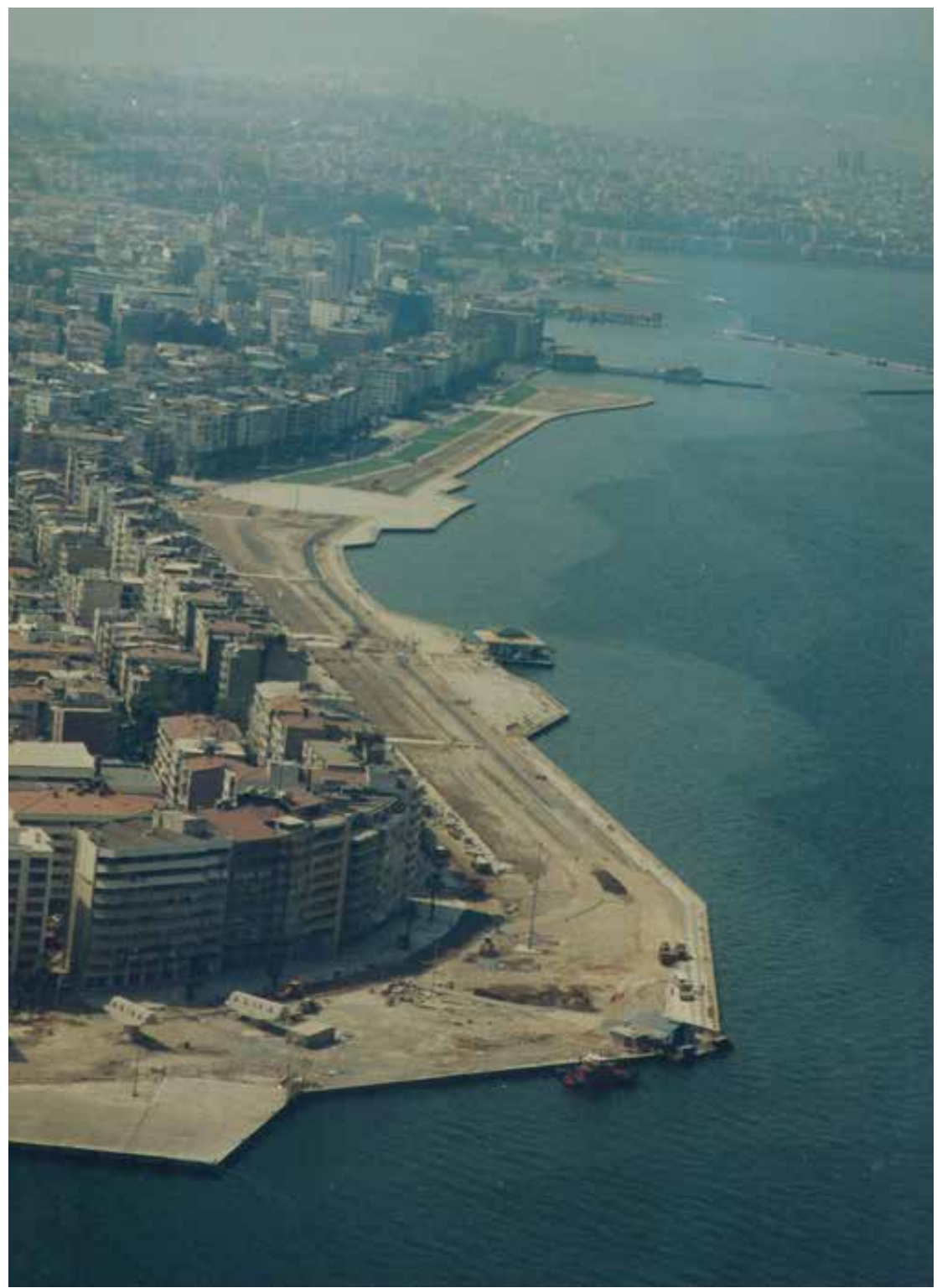

Figure 3. Alsancak Kordonboyu Aerial view from 2000s. Source: Izmir Greater Municipality Media and Public Relations Fund, Ahmet Piriştina City Archive and Museum.

Municipality decided to transform this wreckage into a green urban space, and the new landscape was completed in 2004. In this fresh reclaimed ground, new Alsancak Pier building designed by architect Ahmet Eyüce in 2003 has become the most eye-catching structure on the seaside in this part of the shore (Fig. 4). This square plan steel construction covered with a pitched roof was built in place of the old reinforced concrete one, which was on the same axis but much 


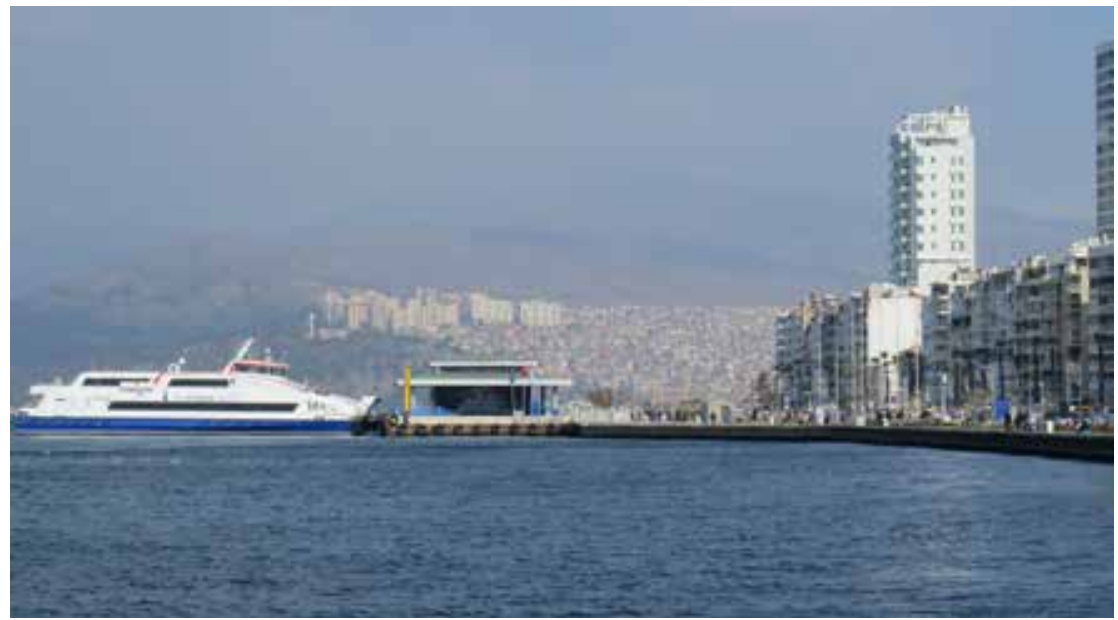

Figure 4. Alsancak Pier. Source: Personal Archive.

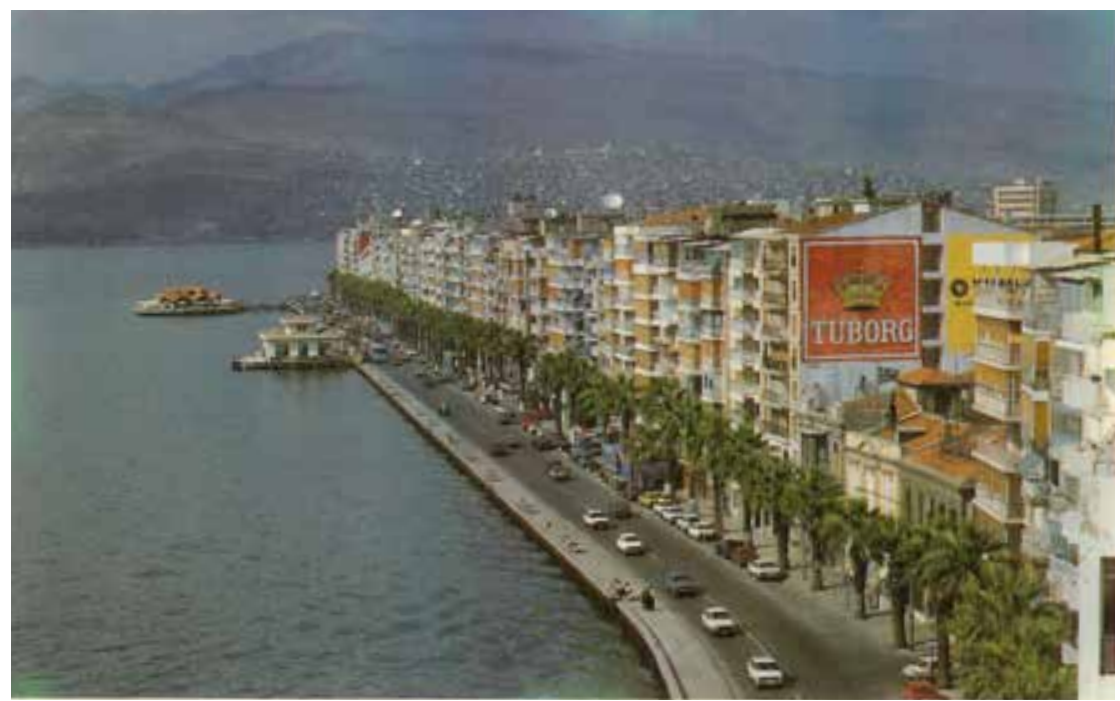

Figure 5. Palet and Alsancak Pier. Source: Adnan-Şükran Ölçücüoğlu Fund, Ahmet Piriştina City Archive and Museum.

closer to the apartment blocks. Before the land reclamation, unlike today, there was another structure on the sea, neighboring the old pier, called Palet Restaurant (Fig. 5). From its opening on March 15, 1984 to its relocation in Bayrakl1 during the highway construction process in the late 1990s, the restaurant had been one of Kordon's most important public focal points and visual symbols especially with its folded roof structure creating an image flying over the sea. In particular, the large outdoor seating area around the restaurant was highly popular for those who meandered along the shoreline.

With their close relationship to the city before the land reclamation, Palet Restaurant and Alsancak Pier seemed as if they were extensions of the "wall" of 


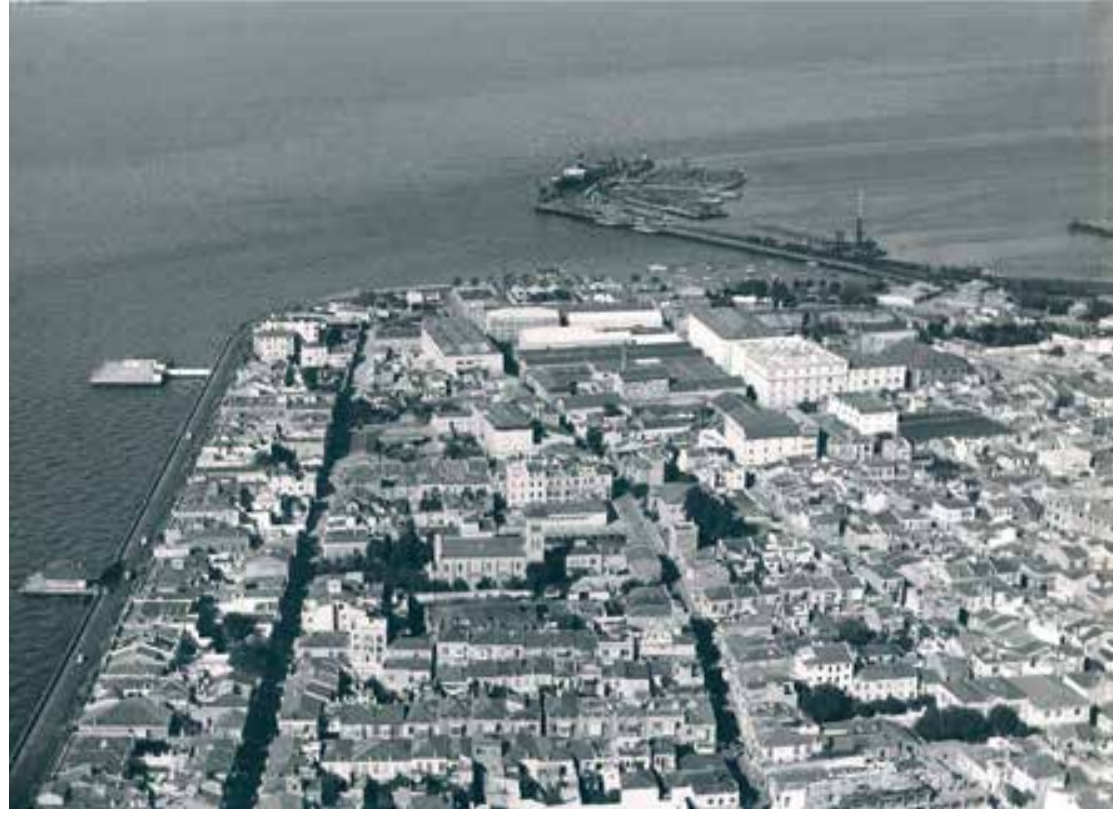

Figure 6. Altay Clubhouse. Adnan-Şükran Ölçücüoğlu Fund, Ahmet Piriştina City Archive and Museum.

the apartment blocks towards the sea. Even though the city seemed like a wall and the usage of public space was highly limited, the line where land met water was much closer to the city and its life before the land reclamation. This walllike formation of blocks first started to rise in late 1960s based on the permissiveness in increasing the building heights provided in the Master Plan of 1955 and the Law of Apartment Ownership of $1964 .{ }^{30}$ Especially the latter caused low-rise buildings with gardens to be replaced by six and seven-storey apartment blocks in less than a decade. ${ }^{31}$ This process deeply changed the urban fabric of the city and the view of the shoreline. Before this change, especially in the period when low-rise buildings of late 19th and early 20th centuries were still defining the waterfront of Punta, old Alsancak Pier and Altay Sports Clubhouse were the only buildings extending above the sea (Fig. 6). Altay Sports Clubhouse was in the place of Palet Restaurant, much closer to the harbor than the pier.

Before the unexpected rise of the cityscape, Altay Clubhouse was an important social meeting place in Alsancak, especially in the years between 1940 and 1950. This L-shaped structure was fronting a large terrace on the waterfront, and at the center of the deck, a pool-like opening allowed the guests to bath in the sea. Those were the years when the sea was still crystal clear and taking a sea bath was in daily routine of those who live by the shore. Erdoğan Tözge, a former President of Altay Sports Club, describes the life in the clubhouse in an

30 Güner, "From Wreckage to Urban Void," 72.

31 Hülya Gölgesiz Gedikler, “1950-1960 yılları arasında İzmir'de Gündelik Yaşam” (PhD diss., Dokuz Eylül University, 2006), 58. 


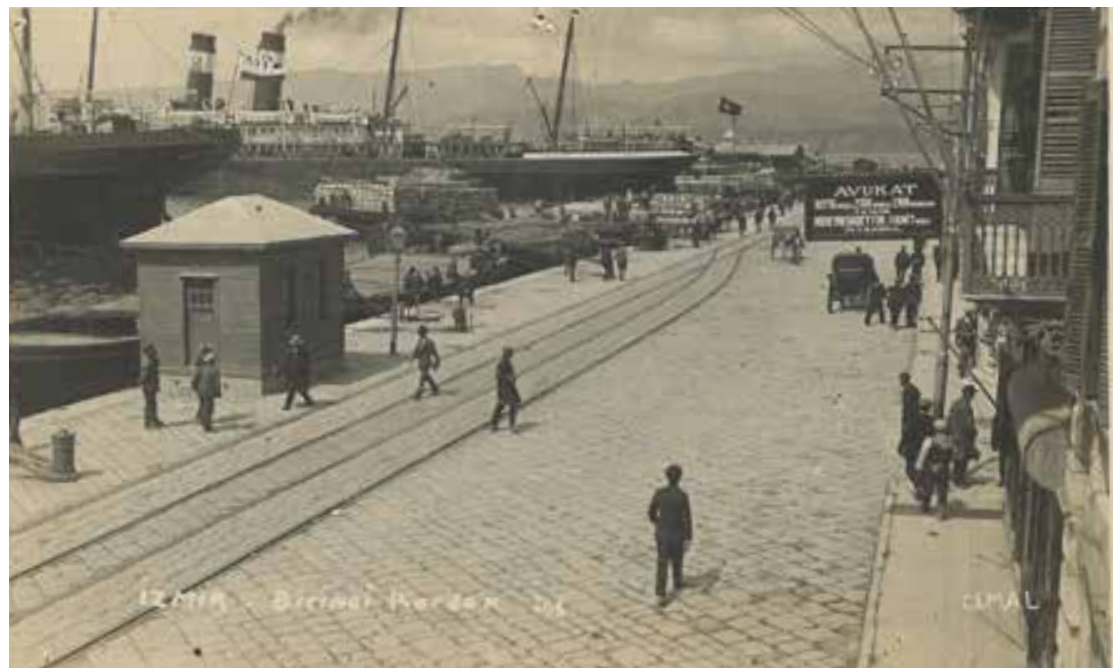

Figure 7. Train Lines of Kordon. Abdullah Erek Donation Fund, Ahmet Piriştina City Archive and Museum.

interview conducted by Yaşar Aksoy as follows:

\begin{abstract}
We spent all our time in Altay Clubhouse over the sea in summer evenings. We slept on the mats of Demirspor wrestlers who exercised at the Clubhouse. We used to swim in the space in the middle of the Clubhouse and we did fishing there, too. Our little kitchen was like nightclub; we played records, drank cold beer, and danced with Emine, an Altay fan who managed the kitchen and whose meatballs were very famous. ${ }^{32}$
\end{abstract}

The Clubhouse building, almost at the end of Kordon axis, was an important landmark. This end of the shoreline in the geography of the harbor had always been a pivotal point, especially for transportation means: such as the trams deployed as the main means of public transport along the shoreline until $1937^{33}$ and the buses afterwards. The rails were used for public transport along Kordonboyu by horse-drawn trams, and for carrying goods to and from the harbor at night and early in the morning by trains. ${ }^{34}$ (Fig. 7 and 8). This railway was constructed according to a contract signed between the Ottoman Government and British entrepreneurs between the Sarı Kışla in Konak and Alsancak Train Station, the last stop of the Aydın-Smyrna railroad. ${ }^{35}$

In fact, this railway was a part of the agreement for the construction of Kordon quays. They were built between 1867 and 1876, by a British company called Smyrna Quay Company, and later by Dussaud Company owing to a privilege pro-

32 Yaşar Aksoy, “Güzel Alsancaklı, Büyük Altaylı,” accessed February 3, 2017, http://www. hurriyet.com.tr/guzel-alsancakli-buyuk-altayli-16452260.

33 Özen Eyüce, “Resimlerle Geçmişten Günümüze Konak,” Ege Mimarlık 35, no. 3 (2000): 6.

34 Erdem Ömüriş, “Bir Kamusal Alan Örneği Olarak Konak Meydanı'nın Mekan Kullanımı Açısından İncelenmesi" (Master thesis, Ege University, 2007), 50.

35 Cana Bilsel, “19. Yüzyılın İkinci Yarısında İzmir'de Büyük Ölçekli Kentsel Projeler ve Kent Mekanının Başkalaşımı," Ege Mimarlık 36, no 4 (2000): 36. 


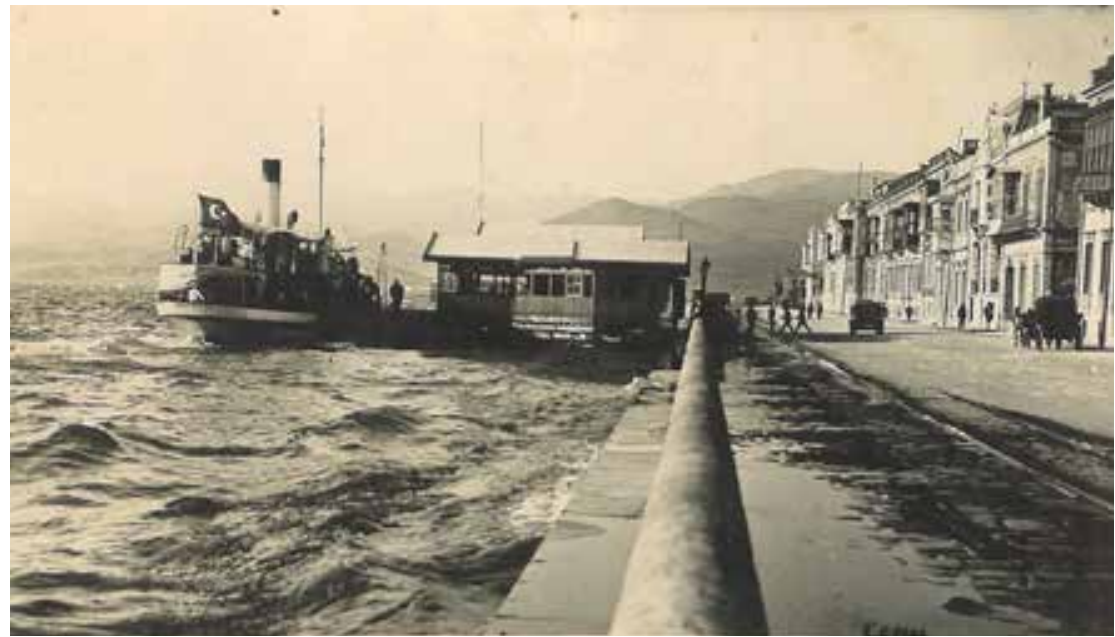

Figure 8. Altay Clubhouse. Adnan-Şükran Ölçücüoğlu Fund, Ahmet Piriştina City Archive and Museum.

vided by the Ottoman State. ${ }^{36}$ Ottoman and foreign press praised the "technical prowess" and "success" of Kordon Quays "as a new element in the urban landscape." ${ }^{37}$ Kordon was described as the centre of social life of the city, by the travelers who visited Izmir in this period. ${ }^{38}$ Until the construction of the quays, Izmir had lacked a port; "arriving ships remained anchored in the gulf, and unloaded their merchandise with small boats which shuttled back and forth between the ships and the custom house." ${ }^{39}$ In fact, in the middle of the second half of the 19th century, the idea of "an open street along the coast, open to public" first emerged with the construction of quays. ${ }^{40}$ Prior to that, direct contact with the sea at Punta was a privilege for wealthy merchants and consulates, which lived or worked in buildings along the waterfront. Apart from a few streets directly opening to the sea, the shoreline of Punta region, in the words of French traveler Joseph Pitton de Tournefort, who visited Izmir in 1702, was almost a sea-dwelling place, where "waves beat houses" in stormy weathers. ${ }^{41}$

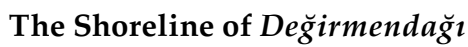

Mustafa Kemal Coastal Boulevard, the six-lane fast vehicle route and incor-

36 Léon Kontente, "Izmir: The Changing Face of a City," in Smyrna in the 18th and 19th Centuries: A Western Perspective. Arkas Sanat Merkezi Catalogue, ed. Jean Luc Maeso and MarieValerie Lesvigne (Istanbul: Mas, 2013), 114.

37 Kontente, "Izmir: The Changing Face of a City," 109.

38 Laurence Abensur-Hazan, "Aspects of Social Life in Smyrna from the 18th to Early 20th Centuries," in Smyrna in the 18th and 19th Centuries: A Western Perspective. Arkas Sanat Merkezi Catalogue, ed. Jean Luc Maeso and Marie-Valerie Lesvigne (Istanbul: Mas, 2013), 125.

39 Kontente, "Izmir: The Changing Face of a City," 109.

40 Rauf Beyru, “19. Yüzyılda İzmir'de Eski İskeleler Hakkında Kısa Bir Not,” Ege Mimarlık 26, no. 2 (1998): 40.

41 Halil İbrahim Alparslan, “19. Yüzyılda İzmir'in Demografik ve Mekansal Durumu,” Ege Mimarlik 89-90, no. 1 (2015): 48. 


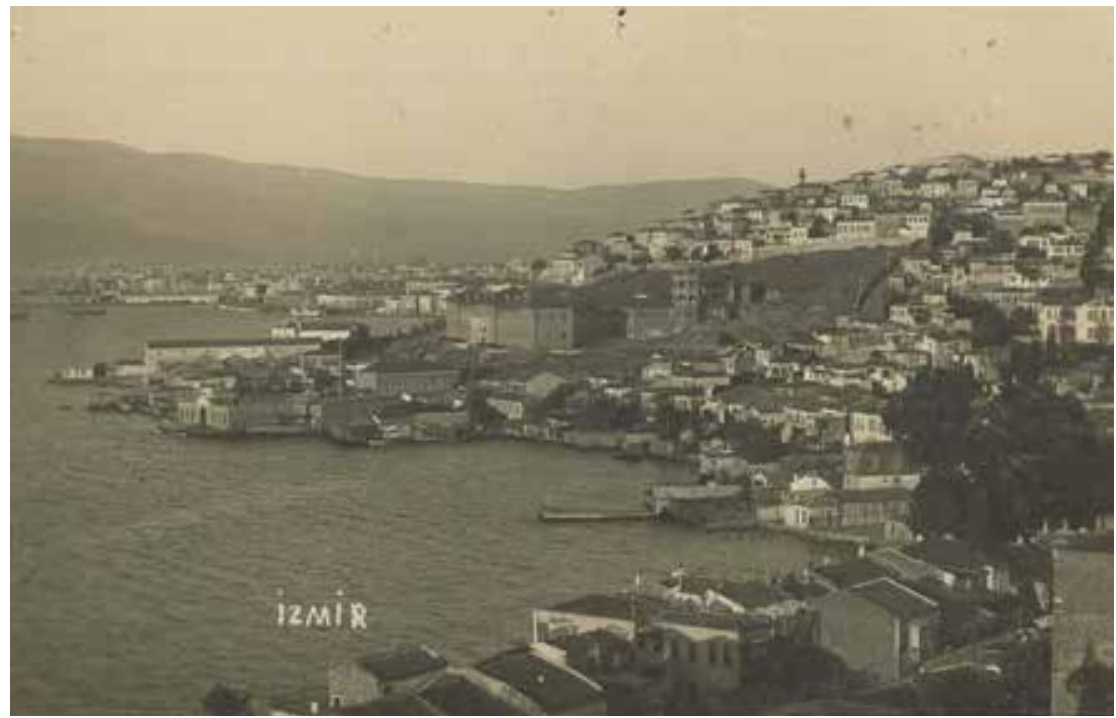

Figure 9. Asansör and Karataş Shoreline. Abdullah Erek Donation Fund, Ahmet Piriştina City Archive and Museum.

porated walkway and tramline at the perimeter constitute the shoreline of Değirmendağ 1 region today. ${ }^{42}$ The construction of this portion of the motorway belt envisioned to surround Izmir's coast was in 1955 Izmir Master Plan. Its construction started in 1977 and completed in 1980s. Before the land reclamations for this motorway, if one had moved from Konak through the shoreline towards southwest direction to Karantina, Köprü, Güzelyal, and Göztepe, it would have been possible for the one to witness a coastal life above the sea level, highly intertwined with the private spaces of the waterfront buildings. Especially before the rapid urbanization in 1960s, when two or three-storey large mansions with gardens were dominating the shoreline, the sea baths and piers provided a privileged minority with an intensive water related life (Fig. 9).

On Değirmendağ 1 side of this region towards the city center, rather than private spaces, cultural and entertainment activities facilitated vibrant city life along the shoreline, especially in the Early Republican Period. Electric trams, shuttling between Konak and Güzelyalı that operated 1929 onwards until the end of $1980 \mathrm{~s}^{43}$ enabled to extend the public life in Konak towards this side of the city. Along with state supported places like Atatürk Culture Center and Public Library, long survived Maksim Gazinosu and Ismet Gazinosu were nightclubs functioning as part of this flow. İsmet Gazinosu, where Officers' Club is situated today, was popular among middle-income families, due to its location just beside the sea and options of open spaces for those who consumed alcohol and who did

42 Derya Öncül, “1980-1983 Sıkıyönetim Döneminin Konak Meydanı,” Ege Mimarlık 59, no. 4 (2006): 24.

43 Eyüce, "Resimlerle Geçmişten Günümüze Konak," 6. 


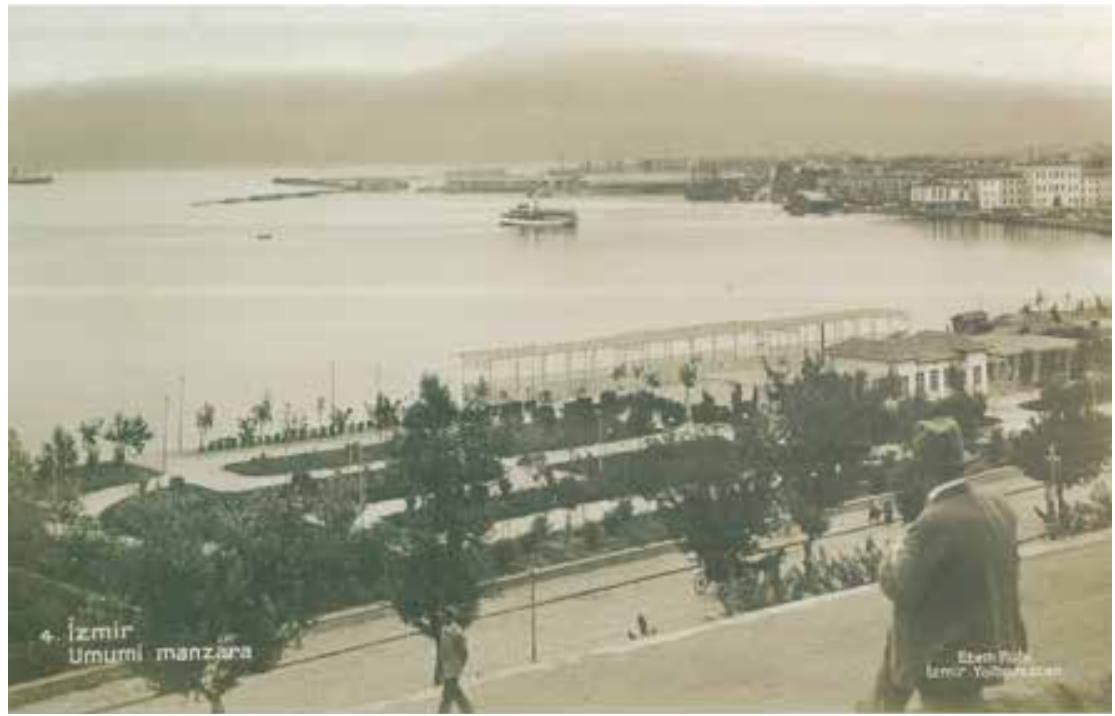

Figure 10. İsmet Gazinosu. Source: Ayla Altınözlü Altay-Tülin Altınözlü IldırAynur Altınözlü Donation Fund, Ahmet Piriştina City Archive and Museum.

not (Fig.10). ${ }^{44}$ An old Izmir citizen, Cavit Kürek expounds one of his memories of this place as follows:

First Hafiz Burhan appeared on the stage. There was no man like Hafez Burhan in singing Gazel. When he started singing, the ones in Karantina, Asansör, Değirmenbaşı, Eşrefpaşa, Damlacık, İkiçeşmelik, and even Asmalımescit neighborhoods could hear his voice. Then, secondly a short, swarthy and skinny girl appeared on the stage. Looking at her posture, one would think that 'this couldn't be the singer, she has one breath life.' However, when she started singing, you would be mesmerized, how can this voice get out from this tiny little girl? This girl's name was Safiye Ayla. ${ }^{45}$

The performance by Safiye Ayla, who was to become a prominent female singer in Turkey, was a prominent event for a nightclub. After presenting many contemporary celebrities, and years of service beside the sea, İsmet Gazinosu first turned into a teahouse, and then closed down during the reclamation process of the shoreline. When it was still open, it was neighboring today's State Theater, Izmir Stage building. The theater building, which has been standing with this function since $1957,{ }^{46}$ was used as a Community House before, and it appeared highly different from its present look. The shoreline, which is far from the building today, was just in front and along with indoor activities, open-air ones such as open-air cinema or bazaar were taking place in its garden, extending along

44 Gölgesiz Gedikler, “1950-1960 Yılları Arasında İzmir'de Gündelik Yaşam,” 521.

45 Cavit Kürek, “İzmir'in Kavakları Bardak Oldu!,” İzmir Kent Kültürü Dergisi 3, no. 1 (2001): 30-31.

46 Gölgesiz Gedikler, “1950-1960 Yılları Arasında İzmir'de Gündelik Yaşam,” 58. 


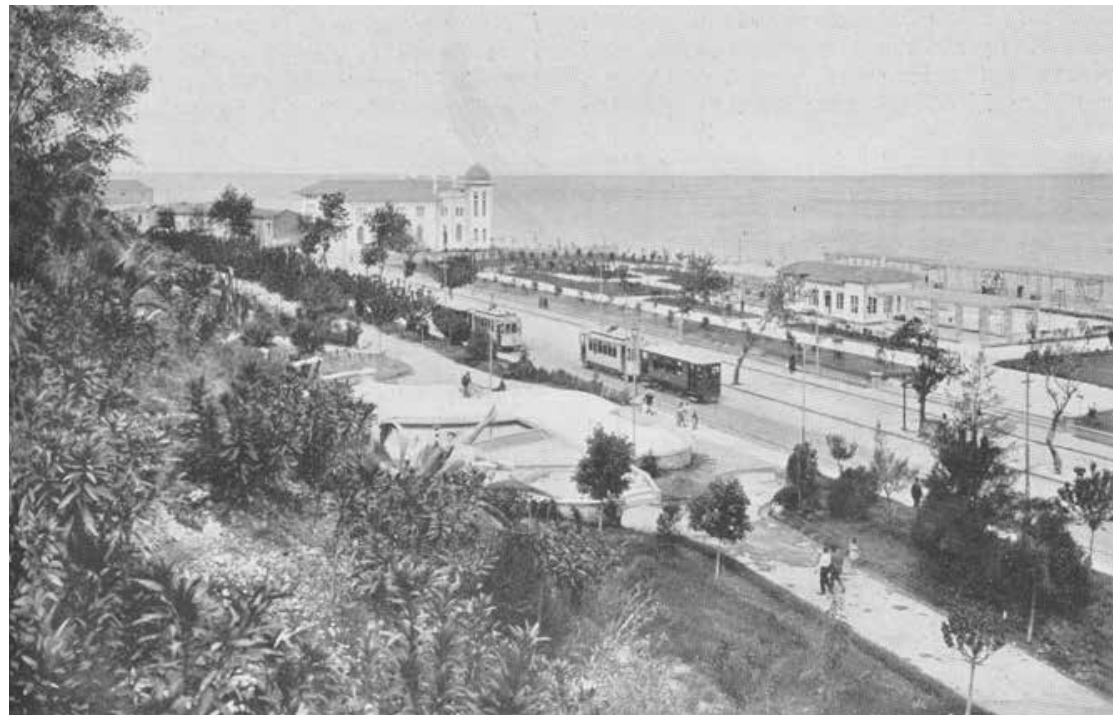

Figure 11. Community House (now Turkish State Theater, Izmir Stage) and İsmet Gazinosu. APIKAM Visual Documents Fund, Ahmet Piriştina City Archive and Museum.

the shoreline (Fig. 11). The building functioned as the Community House until $1951 .{ }^{47}$ However, it was originally constructed in the context of urban transformation plan initiated by the Governor Rahmi Bey, as Türk Ocă̆ı along with Bahri Baba Park at the skirts of Değirmendağı until the building's fate changed when all the national branches of Türk Ocaklart were closed down in 1932.48

Appointed as the Governor of Izmir in 1913, Rahmi Bey aimed to deploy substantial transformations in the urban structure of the city. One of his main objectives was to provide the city with large public edifices, which would be in accordance with its new identity. With this aim, he instructed the construction of Izmir Branch of Türk Ocakları building. Türk Ocakları was one of the pivotal institutions of the late Ottoman Empire, and they sustained their importance during the foundation years of the new Republic in order to establish Turkish identity. ${ }^{49}$ Izmir Branch of Türk Ocakları was one of the most active branches. ${ }^{50}$ Designed by Necmettin Emre in "National Style," also known as "Ottoman Revitalization," Türk Ocakları building of Izmir was completed in 1926. The architectural language of the building included all the attributes of this style from

47 Cengiz Yazıcı, “Türk Ocağı'ndan Devlet Tiyatrosuna," İzmir Kültür ve Turizm Dergisi, accessed 2 June, 2017, http://www.izmirdergisi.com/tr/mimari/687-turk-ocagi-ndan-devlet-tiyatrosu-na.

48 Ayşe Deniz Temiz, “Tarihi Kent Merkezi Kemeraltı'nda 19. Yüzyıldan Bugüne Meydana Gelen Mekansal Dönüşümler," İzmir Kent Kültürü Dergisi 4, no. 2 (2001): 85.

49 François Georgeon, Osmanlı-Türk Modenleşmesi, 1900-1930: Seçilmiş Makaleler, trans. Ali Berktay (Istanbul: Yapı Kredi Yayınları, 2006), 40.

50 Günver Güneş, “Türk Devrimi ve İzmir Türk Ocağı,” Çağdaş Türkiye Araştırmaları Dergisi 3, no. 8 (1998): 111. 


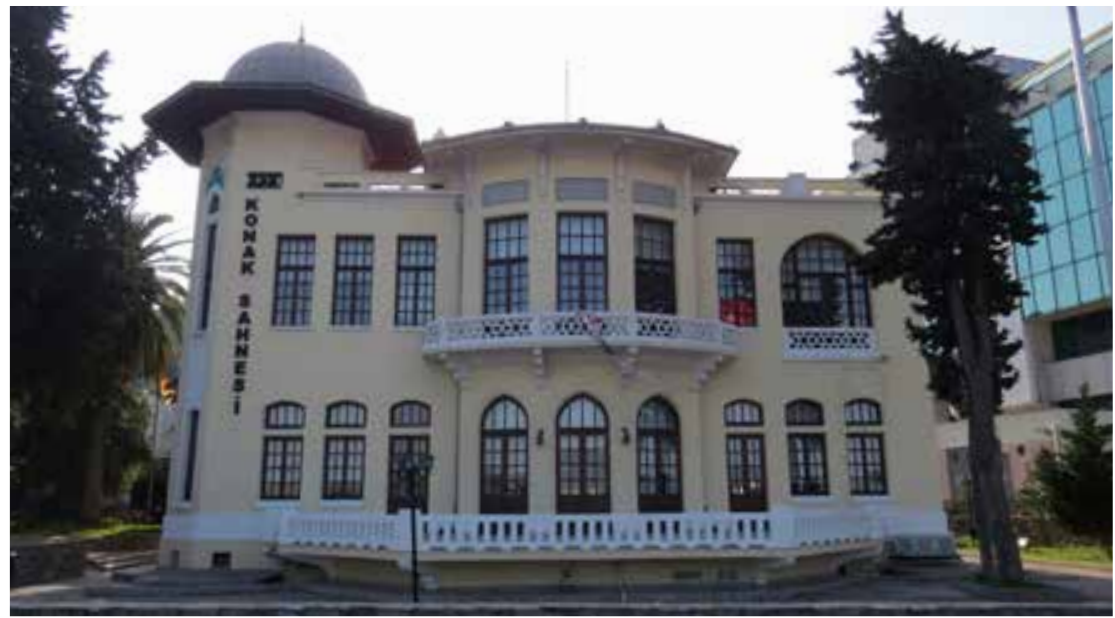

Figure 12. Façade of Türk Ocă̆ı fronting the sea (Turkish State Theater, Izmir Stage today). Source: Personal Archive.

facade ratios to architectural components like fringes, arches and half dome $e^{51}$ (Fig. 12).

Necmettin Emre designed the building's façade looking at the sea as the main façade and he organized common spaces with large windows, terraces and balconies there. Particularly, with the stairs leading to the shore from a large terrace on the ground floor, the architect aimed to enable the life in the building to flow uninterruptedly to the sea. Emre designed this terrace to make the open spaces of the building intertwine with the sea, which is hardly visible from the shoreline today due to the higher ground level of the land reclamations. Rahmi Bey also put in effect some urban strategies to transform the city centre. When he was appointed as the Governor, on the shoreline, Kalafathane buildings and shipyards used for the maintenance of the ships, and on the inland areas, at the skirts of Değirmendağı, a Jewish cemetery had been occupying the connection area between southwest residential part and the more urbanized center of the city (Fig. 13). His first instructions regarding urban transformation included the relocation of cemetery in the outskirts of Izmir and the clearance of Kalafathane area. To this end, in a long process of arduous work, the Jewish Cemetery was relocated and in 1925, Bahri Baba Park was planned on the area. ${ }^{52}$

Before its relocation, this cemetery had been used predominantly by the Jews resettled in this area from İkiçeşmelik and Agora region beforehand, in the context of another development plan that started in $1865 .^{53}$ This development plan formed the urbanization on the outskirts of Değirmendağ 1 in the mid-19th century. ${ }^{54}$ In accordance with this plan, in 1880, Mithatpaşa Street

51 Sibel Bozdoğan, Modernizm ve Ulusun İnşası: Erken Cumhuriyet Türkiyesi'nde Mimari Kültür, trans. Tuncay Birkan (Istanbul: Metis, 2008), 31.

52 Temiz, “Tarihi Kent Merkezi Kemeraltı'nda,” 85.

53 Deniz Güner, ed., İzmir Mimarlık Rehberi (Istanbul: Mas, 2005), 52.

54 Eyüce, “Resimlerle Geçmişten Günümüze Konak,” 4. 


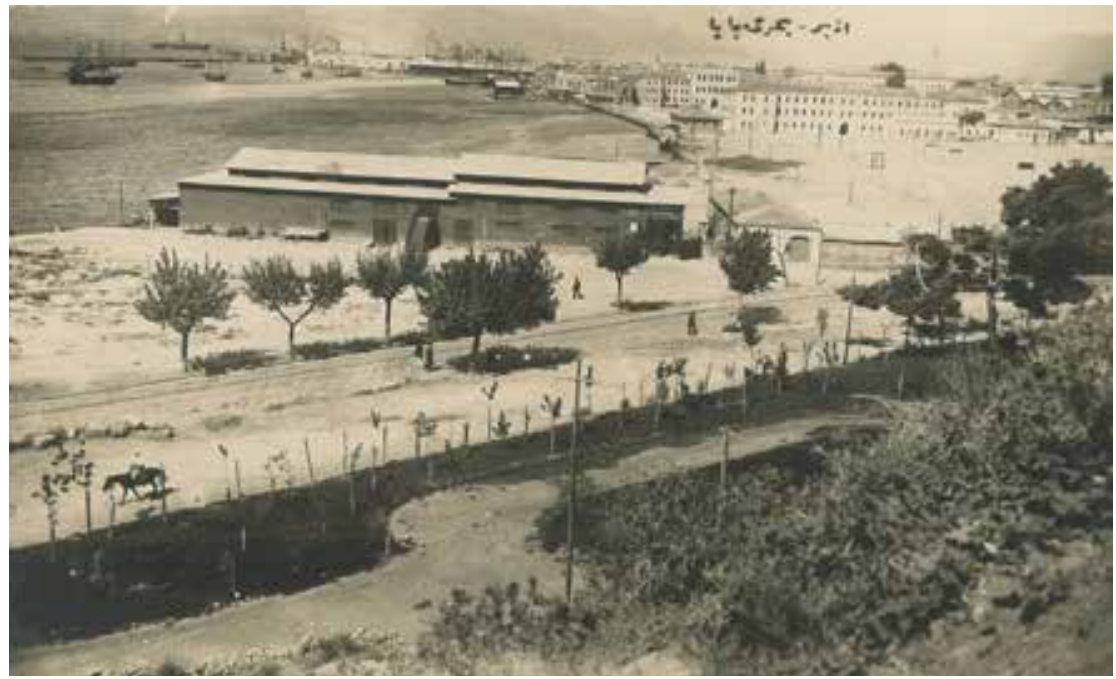

Figure 13. Kalafathane. APIKAM Visual Documents Fund, Ahmet Piriştina City Archive and Museum.

opened for the use of Mithat Pasha himself, Izmir's governor of the period, and in 1883, a tramline for horse-drawn trams was constructed along the street starting from Konak Square and continuing through Karataş-Karantina districts to Göztepe. ${ }^{55}$ With the opening of Halil Rıfat Paşa Street on higher altitude in 1891, the developments in built environment on this direction accelerated. ${ }^{56}$ Before the development plans of 1865, this part of the city was a remote area where the natural shoreline was partially interrupted by suburban towns like Karataş or Göztepe connected to the rest of the city via maritime links or inland roads that open to the sea at intervals.

\section{Konak and Small Harbor}

One of the places in Izmir where the coastal vehicle roads substantially transformed the connection of the urban life with the sea is Konak Square. This huge public space owes its appearance today to the latest transformation project of 2003, designed by architect Ersen Gürsel. When the project was first promoted through the Municipality's billboards, its slogan was "Konak Square is meeting the sea again." ${ }^{\prime 5}$ As the slogan implies, the primary motive behind the whole process was to connect the busy pedestrian flow from old Bazaar Street of Kemeralt 1 to Konak Port. Because, the most prominent feature of Konak Square before the construction of this landscape project was undoubtedly the massive traffic flow along the shoreline. Mithatpaşa Street, stretching from Üçkuyular to Konak, and passing through old Türk Ocă̆l, was on the axis between Yalı

55 Ömüriş, “Bir Kamusal Alan Örneği Olarak Konak Meydanı́nın Mekan Kullanımı Açısından İncelenmesi," 49.

56 Deniz Güner, ed., İzmir Mimarlık Rehberi (Izmir: Mimarlar Odası İzmir Şubesi, 2005), 52.

57 Ersen Gürsel, et al. “Konak Meydanı ve Çevresi Düzenleme Projesi. Konak Meydanı Denizle Yeniden Buluşuyor," Ege Mimarlık 50, no. 2 (2004): 44. 


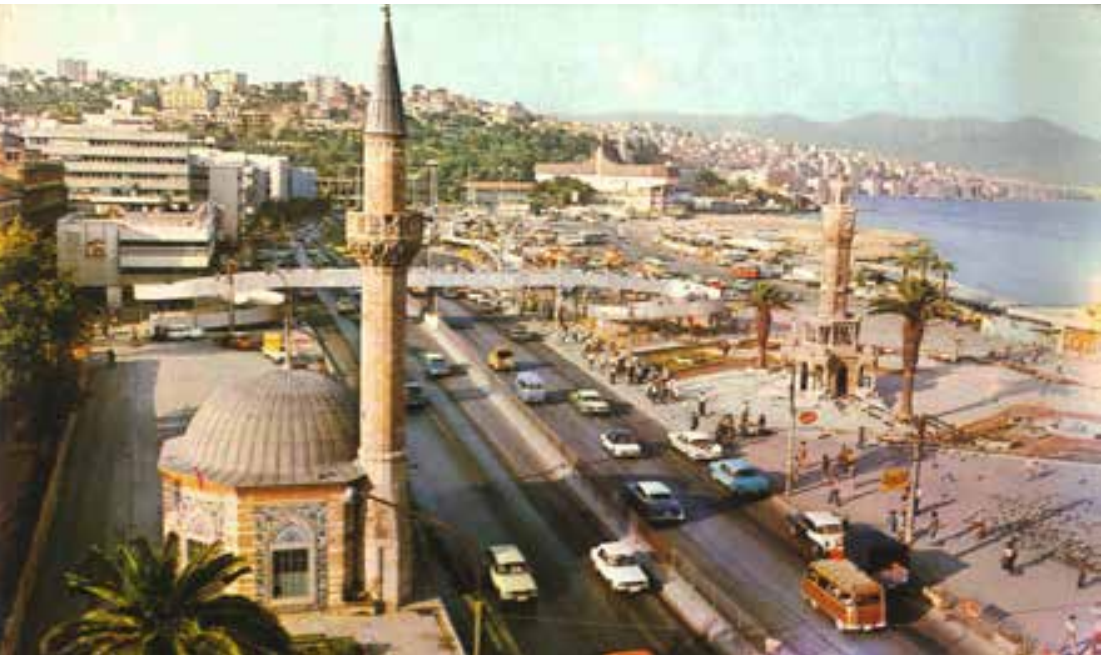

Figure 14. Yalı Mosque and the Clock Tower in Konak Square, a Postcard from the 1980s. Personal Archive.

Mosque and the Clock Tower. Along with the increasing traffic density over the years, a pedestrian bridge was built over the road to connect Bazaar and the Port (Fig. 14). All these attempts in different periods indicate that, even though the size of the public space of the square increased in time, its connection with the shoreline has gradually weakened with each land reclamation.

While the main objective of the project prepared by Ersen Gürsel was to overcome this rupture, another one was to remind the citizens of the symbolic buildings of the plaza, which had been demolished and erased from the memory of the city. Undoubtedly, the most important one of these buildings was Barracks called Sarı Kışla occupying the entire shoreline. Gürsel emphasized the outer edges of this vanished building in his landscape design, so the footprints of this forgotten structure became discernable. ${ }^{58}$ What is more interesting in the history of Konak Square is the fact that even Sarı Kışla itself was built through reclamation in 1827, by using the marbles of the ancient Smyrna city stadium and the amphitheater. ${ }^{59}$ Occupying a large space on the shore, the building was right across the present National Library, extending along that street up to the entrance of Old Bazaar Street of Kemeraltı, until its demolition between 1955 and 1957. With this huge massive area that it covers, it was one of the main elements that created the identity of Konak Square from its construction to destruction.

In fact, the appearance and everyday use of Konak Square at the beginning of the 20th century was substantially different from its identity in the present, especially when Sarı Kışla was still standing. The Clock Tower, designed by Reynolds and opened on September 1, 1901 to mark the 25th anniversary of Abdulhamid II's coronation, was at the center of a quite small, but highly defined public space. The old Konak Port on the shoreline and the tramline that

58 Gürsel, "Konak Meydanı ve Çevresi Düzenleme Projesi," 45.

59 Eyüce, “Resimlerle Geçmişten Günümüze Konak," 4. 


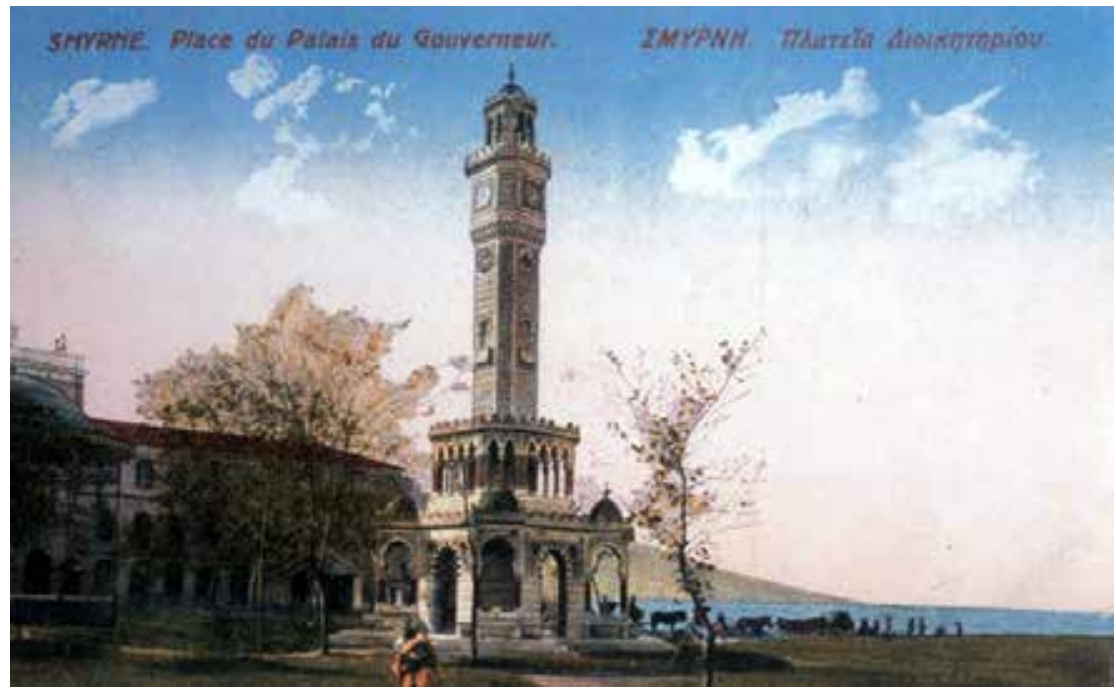

Figure 15. Sarı Kışla and the Clock Tower. APIKAM Visual Documents Fund, Ahmet Piriştina City Archive and Museum.

replaced the horse car, revolving around the Clock Tower provided the area with easy access (Fig. 15). ${ }^{60}$ Although the tramlines were dismantled in 1941 and left their places to buses and trolleybuses, the square kept its importance for the city's social life. ${ }^{61}$ The pastry shop at the Kemeraltı corner of this square on the ground floor of Ankara Palas hotel that was built in $1938^{62}$ was an important meeting point for prominent politicians and journalists of the city during the 1940s and 1950s. ${ }^{63}$ There was also a luxury restaurant on the first floor of the newly built concrete Konak Port, which replaced the old timber structure. ${ }^{64}$

Konak Square of those years was a smaller public space, but with a better contact with the shoreline. As can be understood from the specifications of the architectural and urban design competitions opened for this area in 1951 and 1956, this identity of the square was attempted to be preserved even after the demolition of Sarı Kışla. However, the projects obtained through these two competitions were never put into use. ${ }^{65}$ Between 1955 and 1980, most of the public buildings surrounding the square, inherited from Ottoman period, such as warehouses, customs buildings and the courthouse were demolished. ${ }^{66}$ Even today's Government House could not preserve its original form, since it was

60 Orhan Ekinci, “Tramvay İzmir'de de 'Vard1'...," Ege Mimarlık 2 (1991): 46.

61 Öncül, "1980-1983 Sıkıyönetim Döneminin Konak Meydanı,” 24.

62 Gürsel, "Konak Meydanı ve Çevresi Düzenleme Projesi," 45.

63 Gölgesiz Gedikler, “1950-1960 yılları arasında İzmir'de Gündelik Yaşam,” 512.

64 Gölgesiz Gedikler, “1950-1960 yılları arasında İzmir'de Gündelik Yaşam,” 509.

65 "İzmir Şehri İmar Plânı. Milletlerarası Proje Müsabakası Proğramı. 1 Mayıs 1951-1 Aralık 1951," Arkitekt 249-52, no. 5-8 (1952): 144-146; “İzmir Konak Sitesi Proje Musabakası," Arkitekt 284, no. 2 (1956): 57-73.

66 Ömüriş, “Bir Kamusal Alan Örneği Olarak Konak Meydanı́nın Mekan Kullanımı Açısından İncelenmesi," 49. 
rebuilt after its total destruction in a fire in 1970, with a totally new architectural approach, merely imitating its facade features. In fact, the square was named after Katipoğlu Konăgl, which was situated in the place of the old Government house. ${ }^{67}$ Yal Mosque, on the other hand, is the oldest surviving structure in the square with its original features. The mosque, which was built together with a madrasa complex in 1755, was originally known as Ayşe Hatun, but referred as Yal1, meaning "building on the shore" in Turkish, due to its former position just beside the sea. ${ }^{68}$ Imagining today's Yalı Mosque on the shoreline can be challenging for many, but it surely would be more difficult to visualize this entire area as a small bay used as a harbor called Sandal Limant until the 18th century. ${ }^{69}$

Sandal Limani, which had been important for Izmir's role in sea-trade as the natural port of the city since antiquity, began to be closed through land reclamation ordered by Timur when he invaded the city in 1402 for defensive reasons. Since then, the bay was reclaimed gradually for centuries. When the British traveler Chandler visited the city in 1764 , the bay was somehow still visible, since he described it in his memoir as a large open space that regularly flooded and turned into a small lake when it rained. ${ }^{70}$ In the course of the 19th century, however, the open space that lingered for a while as the reminiscence of the bay became totally invisible due to new buildings. ${ }^{71}$ Evliya Çelebi, during his visit between 1670 and 1671, described this bay in his Seyahatname, travelogue in Turkish, as a small harbor with a fortress on one side. ${ }^{72}$ Called Ok Kalesi or Sancak Kalesi, this fortress, which had been one of the most symbolic features of Izmir's shoreline for centuries, and completely forgotten today, was located at the northern end of Sandal Limanı alongside today's Hisar Mosque. ${ }^{73}$ In his travelogue, Çelebi described this fortress saying that "there is an icy water well in the fortress gate, finding that sweet water in a fortress in the middle of the sea is astonishing." ${ }^{74}$ Today, the fortress and the bay reside hidden in the dense urban fabric of predominantly 19th century buildings. Only those, who know the story of the place, can unravel the traces of the old shoreline surrounded by Anafartalar Street today. Despite the presence of embankment elements in the least expected places around this forgotten bay, the city meets the sea hundreds of meters away.

\section{Conclusion}

If memory is composed of what is remembered and forgotten concurrently, in this equation, the proportion of the forgotten life and spaces are much greater

67 Eyüce, "Resimlerle Geçmişten Günümüze Konak,” 4.

68 Ömüriş, “Bir Kamusal Alan Örneği Olarak Konak Meydanı́nın Mekan Kullanımı Açısından İncelenmesi," 48.

69 Rauf Beyru, “Geçmişten Günümüze İzmir'de Planlama ve İmar Uygulamaları,” Ege Mimarlık 3 (1991): 42.

70 Beyru, “Geçmişten Günümüze İzmir'de,” 46.

71 Alparslan, “19. Yüzyılda İzmir'in Demografik ve Mekansal Durumu,” 47.

72 Evliya Çelebi, Seyahatname, vol. 8 (Istanbul: Üçdal Neşriyat, 1986), 535.

73 Galip Ergeneci, “Unutmayalım Diye,” Ege Mimarlık 15, no. 1 (1995): 39.

74 Evliya Çelebi, Seyahatname, 531. 
than the remembered ones for the memory of the shoreline of Izmir. Although the bright side is that public spaces on the shoreline superseded the private spaces like mansions, shipyards or officers' buildings as a result of some of these reclamations, what is lost in terms of memory of the previous life on the shoreline is irreplaceable. The culture of socialization above the sea disappeared in Alsancak, direct contact with the sea fell away due to the construction of Mustafa Kemal Sahil Boulevard, or small harbor of Kemeraltı turned into a dense built environment. Considering the significant role of space as a vessel for the endurance of memory, it is possible to claim that the land reclamations on the shoreline of Izmir caused an erasure of the collective memory and thus erosion of the city life culture in return.

Backwards reading of particular areas in Izmir indicated that the land reclamations that have been gradually employed in the urbanization process of the city reproduced the shoreline perpetually along with its memory. With each reclamation attempt, the places on the shoreline were either demolished or kept with new contextual conditions. Even in the case that the buildings were preserved, they turned into haunted shells of their previous lives. Since, the everyday life facilitated by these places was forced to transform, so that the previous life in them became memory, sometimes leaving unidentified voids in the city life and/or unrecognized traces in the urban fabric. When the land reclamations of different periods overlapped gradually, and the living memory of the previous shoreline disappeared, this memory turned into history as the reconstruction of the past in which the real life is hardly told.

\section{Bibliography}

Abensur-Hazan, Laurence. "Aspects of Social Life in Smyrna from the 18th to Early 20th Centuries." In Smyrna in the 18th and 19th Centuries: A Western Perspective. Arkas Sanat Merkezi Catalogue, edited by Jean Luc Maeso and Marie-Valerie Lesvigne, 119-127. Istanbul: Mas, 2013.

Aksoy, Yaşar. “Güzel Alsancaklı, Büyük Altaylı.” Accessed February 3, 2017. http://www. hurriyet.com.tr/guzel-alsancakli-buyuk-altayli-16452260.

Alparslan, Halil İbrahim. “19. Yüzyılda İzmir'in Demografik ve Mekansal Durumu.” Ege Mimarlık 89-90, no. 1 (2015): 46-49.

Arkayın, Tufan. "Kazıklı Yol... Dolgu Yol... Kordon Yolu... Hizlı Yol, Hiz Yolu." Ege Mimarlik 2 (1992): 31-32.

Beyru, Rauf. “19. Yüzyılda İzmir'de Eski İskeleler Hakkında Kısa Bir Not.” Ege Mimarlık 26, no. 2 (1998): 40-41.

Beyru, Rauf. “Geçmişten Günümüze İzmir'de Planlama ve İmar Uygulamaları.” Ege Mimarlik 3 (1991): 41-47.

Bilsel, Cana. “19. Yüzyılın İkinci Yarısında İzmir'de Büyük Ölçekli Kentsel Projeler ve Kent Mekanının Başkalaşımı." Ege Mimarlık 36, no 4 (2000): 34-37.

Bozdoğan, Sibel. Modernizm ve Ulusun İnşası: Erken Cumhuriyet Türkiyesi'nde Mimari Kültür. Translated by Tuncay Birkan. İstanbul: Metis, 2008.

Casey, Edward. Remembering: A Phenomenological Study. Second Edition. Bloomington: Indiana University Press, 2000. 
Ekinci, Orhan. “Tramvay İzmir'de de ‘Vard1'...” Ege Mimarlık 2 (1991): 46.

Ergeneci, Galip. “Unutmayalım Diye.” Ege Mimarlık 15, no. 1 (1995): 37-44.

Evliya Çelebi. Seyahatname. Volume 8. Istanbul: Üçdal Neşriyat, 1986.

Eyüce, Özen. “Resimlerle Geçmişten Günümüze Konak.” Ege Mimarlık 35, no. 3 (2000): 4-8.

Gedikli, Bahar. "Kıyıуı Yaşamak, Kıyıyı Planlamak.” In 7. Kıyı Mühendisliği Sempozyumu Bildiri Kitabı 21-23 Kasım 2011, edited by Prof. Dr. Yalçın Yüksel, 23-33. Trabzon: TMMOB İnşaat Mühendisleri Odası, 2011.

Georgeon, François. Osmanlı-Türk Modenleşmesi, 1900-1930: Seçilmiş Makaleler. Translated by Ali Berktay. Istanbul: Yapı Kredi Yayınları, 2006.

Gölgesiz Gedikler, Hülya. “1950-1960 yılları arasında İzmir'de Gündelik Yaşam.” PhD diss., Dokuz Eylül University, 2006.

Grydehøj, Adam. "Making Ground, Losing Space: Land Reclamations and Urban Public Space in Island Cities." Urban Island Studies, 1 (2015): 96-117.

Güner, Deniz, ed. İzmir Mimarlık Rehberi. Izmir: Mimarlar Odası İzmir Şubesi, 2005.

Güner Deniz. "From Wreckage to Urban Void: Izmir's Kordonboyu Waterfront Redevelopment." In Architecture in Turkey Around 2000: Issues in Discourse and Practice, edited by Tansel Korkmaz, 71-96. Ankara: Türkiye Mimarlar Odası, 2005.

Gürsel, Ersen et al. "Konak Meydanı ve Çevresi Düzenleme Projesi. Konak Meydanı Denizle Yeniden Buluşuyor." Ege Mimarlık 50, no. 2 (2004): 44-53.

Güneş, Günver. “Türk Devrimi ve İzmir Türk Ocağı.” Çağdaş Türkiye Araştırmaları Dergisi 3, no. 8 (1998): 115-136.

Güven, Pelin. “İzmir Kentinde Rekreasyon Amaçla Yapılan Kıyı Dolgu Alanlarının Peyzaj Planlama Açısından İrdelenmesi: İzmir-İnciraltı Örneği.” Master thesis, Istanbul Technical University, 2000.

Halbwachs, Maurice. The Collective Memory. Translated by Francis J. Ditter and Vida Yazdi Ditter. New York: Harper and Row, 1980.

Hayden, Dolores. The Power of Place: Urban Landscapes as Public History. Cambridge, Mass.: MIT Press, 1995.

Hooke, J. M. and R. C. Riley, "Historical Changes on the Hampshire Coast, 1870-1965." Proceedings of the Hampshire Field Club and Archaelogical Society 47 (1991): 203-224.

Hutton, Patrick H. History as an Art of Memory. Hanover: University Press of New England, 1993.

Huyssen, Andreas. Twilight Memories: Marking Time in a Culture of Amnesia. London; New York: Routledge, 1994.

“İzmir Şehri İmar Plânı. Milletlerarası Proje Müsabakası Proğramı. 1 Mayıs 1951-1 Aralık 1951," Arkitekt 249-52, no. 5-8 (1952): 144-146.

“İzmir Konak Sitesi Proje Musabakası.” Arkitekt 284, no. 2 (1956): 57-73.

Kontente, Léon. "Izmir: The Changing Face of a City." In Smyrna in the 18th and 19th Centuries: A Western Perspective. Arkas Sanat Merkezi Catalogue, edited by Jean Luc Maeso and Marie-Valerie Lesvigne, 108-127. Istanbul: Mas, 2013.

Kusno, Abidin. The Appearances of Memory: Mnemonic Practices of Architecture and Urban Form in Indonesia. Durham; London: Duke University Press, 2010.

Kürek, Cavit. “İzmir'in Kavakları Bardak Oldu!.” İzmir Kent Kültürü Dergisi 3, no. 1 (2001): 28-31.

Misztal, Barbara A. Theories of Social Remembering. Berkshire: McGraw-Hill Education, 2003. 
Ng, Mee Kam and Alison Cook. "Reclamation: An Urban Development Strategy Under Fire." Land Use Policy 14 (1997): 5-23.

Nora, Pierre. "Between Memory and History: Les Lieux de Mémoire." Representations 26 (1989): 7-25.

Ömüriş, Erdem. "Bir Kamusal Alan Örneği Olarak Konak Meydanı́nın Mekan Kullanımı Açısından İncelenmesi." Master thesis, Ege University, 2007.

Öncül, Derya. "1980-1983 Sıkıyönetim Döneminin Konak Meydanı." Ege Mimarlk 59, no. 4 (2006): 22-25.

Pramesti, Rochana Esti. "Sustainable Urban Waterfront Redevelopment: Challenge and Key Issues." Media Matrasain 14, no. 2 (2017): 41-54.

Temiz, Ayşe Deniz. “Tarihi Kent Merkezi Kemeraltı́nda 19. Yüzyıldan Bugüne Meydana Gelen Mekansal Dönüşümler." İzmir Kent Kültürü̈ Dergisi 4, no. 2 (2001): 81-91.

Thompson, Richard F. and Stephen A. Madigan. Memory: The Key to Consciousness. Washington: Joseph Henry Press, 2005.

Topal, Hasan. “Kordon Dolgu Alanının Bir Kentsel Mekana Dönüşümü." Ege Mimarlk 35, no. 3 (2000): 18-19.

Uzun, İnci T., Didem Akyol Altun and Eylem Bal. “İzmirli'nin İzmir'i: Kentlinin Belleğindeki Mekânsal Temsiller." Ege Mimarlık 76, no. 1 (2011): 34-39.

Yazıc1, Cengiz. "Türk Ocağı'ndan Devlet Tiyatrosuna." İzmir: Kültür ve Turizm Dergisi, http://www.izmirdergisi.com/tr/mimari/687-turk-ocagi-ndan-devlet-tiyatrosu-na. Accessed 2 June, 2017.

Yeung, Yue-man. "Coastal Mega-cities in Asia: Transformation, Sustainability and Management." Ocean \& Coastal Management 44, no. 5-6 (2001): 319-333. 